\title{
Effect of integrated farmyard manure and NP fertilizers use on hybrid maize yield and soil properties in western Ethiopia
}

\author{
Bekele Gemechu ${ }^{1 \star}$, Ayana Etana ${ }^{2}$, Feyera Senbeta ${ }^{1}$ and Degefa Tolossa ${ }^{1}$ \\ ${ }^{1}$ College of Development Studies, Addis Ababa University, Ethiopia. \\ ${ }^{2}$ Jimma University College of Agriculture and Veterinary Medicine, Ethiopia. \\ Accepted 7 June, 2017
}

\begin{abstract}
A study was carried out to assess the effect of integrated Farmyard Manure (FYM) and inorganic NP fertilizers use on yield and soil properties in Bako-Tibe district of Oromia, western Ethiopia. Five treatments (that is, $110 \mathrm{~kg} \mathrm{~N} \mathrm{ha}^{-1}+46 \mathrm{~kg} \mathrm{P}_{2} \mathrm{O}_{5} \mathrm{ha}^{-1}$ (T1), 12 ton FYM ha ${ }^{-1}$ (T2), $55 \mathrm{~kg} \mathrm{~N}^{-1}+23 \mathrm{~kg} \mathrm{P}_{2} \mathrm{O}_{5} \mathrm{ha}^{-1}+6$ ton FYM ha ${ }^{-1}$ (T3), $27.5{\mathrm{~kg} \mathrm{~N} h \mathrm{~h}^{-1}+11.5 \mathrm{~kg} \mathrm{P}_{2} \mathrm{O}_{5} \mathrm{ha}^{-1}+6 \text { ton FYM ha }}^{-1}$ (T4) and the control (T5)) were used in a Randomized Complete Block Design (RCBD) with five replications using five farmers' fields. Yield and yield related parameters were analyzed using SAS statistical software version 9.0. Economic analysis was performed to compare treatments advantages. The treatment with half the recommended NP $\left(55 \mathrm{~kg} \mathrm{~N} \mathrm{ha}^{-1}\right.$ $+23 \mathrm{~kg} \mathrm{P}_{2} \mathrm{O}_{5} \mathrm{ha}^{-1}+6$ ton $\mathrm{FYM} \mathrm{ha}{ }^{-1}$ ) showed superior plant growth performance as compared to other treatments. Pure use of inorganic NP resulted in high $\mathrm{Na}, \mathrm{K}, \mathrm{Ca}$ and $\mathrm{P}$ composition of grain while pure FYM use resulted in high content of $\mathrm{Mg}$ and $\mathrm{Ca}$ composition. The level of $\mathrm{P}$ in grain decreased with the increasing of FYM. Soil fertility parameters considered showed no significance difference (P: 0.05) among the treatments. The mean difference values indicated that use of pure inorganic fertilizer increased soil $\mathrm{PH}$, exchangeable $\mathrm{Na}$, and available $\mathrm{S}$. Use of pure farmyard manure resulted in an increase in the soil exchangeable $\mathrm{Na}, \mathrm{K}, \mathrm{Mg}$, total nitrogen, and available $\mathrm{K}$ and $\mathrm{S}$. The use of half of the recommended inorganic fertilizer and FYM can enhance soil fertility in addition to yield improvement.
\end{abstract}

Keywords: Bako Tibe, hybrid maize, nutritional composition, participatory approach.

*Corresponding author. E-mail: oliyad.hn2@gmail.com.

\section{INTRODUCTION}

Maize has grown in Africa as a popular and widely cultivated food crop since its introduction to the continent around 1500 A.D. (McCann, 2005). Likewise, it is grown as a subsistence crop in the mid-altitudes (1500 to 2000 $\mathrm{m}$ above sea level) in southern, south-central, and southwestern parts of Ethiopia (Abate et al., 2015). It accounts for the largest share in total production and the total number of farm holdings involved among cultivated cereals in Ethiopia. In 2010/11 cropping season, maize accounted for 28 percent of the total cereal production, and about eight million smallholders were involved in maize production in the country (Demeke, 2012). The popularity of maize in Ethiopia is partly because of its high value as a food crop and the growing demand for the stover as animal fodder and source of fuel for rural families (Getachew, 2015; Abate et al., 2015).

Like elsewhere, maize is the major crop grown and covering about $46 \%$ of the total land cultivated every year in the study area, Bako Tibe District (Getachew, 2015). Of the total cultivable land in the study area, Alfisol which is known for its low fertility due to its acid forming cations (Fe and $\mathrm{Al}$ ) covers about $56 \%$ of the area (Heluf and Negassa, 2006). Alfisol is deficient in boron and phosphorus due to the inherent nature of the soil and $\mathrm{Fe}$ $\mathrm{P}$ and Al-P fixation as a result of soil acidification due to acid forming fertilizer application. The high availability of 
active $\mathrm{Al}$ and $\mathrm{Mn}$ in the soil resulted in low $\mathrm{pH}$ values, low level of OC, lower available $S$ and $P$ and lower extractable B and Z (Getachew, 2015). Importantly, continuous cultivation, mono-cropping of maize and intensive tillage has been the contributing factors for the depletion of soil nutrients in the study area (Breman, 2007).

Chemical fertilizer application is very minimal when compared to the amount of nutrient extracted (Getachew, 2015); and during the harvest, the crop is cleared to the ground level without any crop residue left on the field. Farmers rarely apply organic matters like FYM on their field except very few farmers who apply on their homestead. This and the other summoned problems all together constraining maize production and productivity in this part of the country in general and in Bako Tibe district (the potential maize producing area of the region) in particular (Negassa et al., 2005). The ever increasing price of inorganic fertilizers and the high deterioration rate of soil nutrients are seeking immediate solution before the problems worsen. To combat this challenge, soil fertility management through the use of alternative soil fertility replenishment is highly indispensable. Various studies (Belay et al., 1998, Negassa et al., 2005) have indicated that application of FYM and other organic nutrients enhanced soil fertility and improved crop yields and sustained productivity when integrated with inorganic fertilizers. The presence of high cattle population in the district can create an opportunity for availability of enormous amount of cattle manure or FYM in the study area. In the present study, the authors evaluated the impact of integrated FYM and NP fertilizer application on hybrid maize yield and yield components and soil properties at Bako-Tibe district in Western Ethiopia.

\section{MATERIALS AND METHODS}

\section{Study area description}

The study site (Bako Tibe district) is located in humid agro-ecology of west Shewa zone of Oromia Regional State at $9^{\circ} 08^{\prime} \mathrm{N}$ latitude and $37^{\circ} 03^{\prime} \mathrm{E}$ longitude; about $250 \mathrm{~km}$ west of Addis Ababa. The altitudinal range of the study area is from 1727 to $1778 \mathrm{~m}$. The long term weather information revealed that the area has unimodal rainfall pattern extending from March to October, but the effective rain is from May to September (Dadhi et al., 1987). The mean annual rainfall is about $1237 \mathrm{~mm}$, with a peak in July. It has a warm humid climate with annual mean minimum and maximum temperature of 14 and $29^{\circ} \mathrm{C}$, respectively and the mean annual temperature is $20^{\circ} \mathrm{C}$.

In term of soil, the study area is characterized by brown clay loam Alfisol which has low total nitrogen, low organic carbon (OC) and low available phosphorus (Negasa, 2001; Mesfin, 1998).

Generally, all soils, as soils of agricultural land, have been intensively cultivated over a long period of time as the main livelihood means. The major constraints of soils in the Bako Tibe district include low level of nitrogen, soil acidity, poor drainage, flooding and logging problems. Thus, in order to enhance agricultural productivity, specific measures need to be taken to correct the specific problems of each soil type. The dominant crop grown in the study area is maize (Zea mays) (46\%) and followed by teff (Eragrostis tef) (23\%). Crop-livestock farming system has been practiced among the small holder farmers in the study area.

\section{Treatments}

In the present study, five treatments were compared. Of these, two treatments were set based on previously recommended NP and FYM rate (by Bako Agricultural Research Center for maize in western Oromia as: Treatment 1 (T1) $=110 \mathrm{~kg} \mathrm{~N} \mathrm{ha}^{-1}+46 \mathrm{~kg} \mathrm{P}_{2} \mathrm{O}_{5}$ ha $^{-1}$ (Recommended NP fertilizer); Treatment 2 (T2) = 12 ton FYM ha $^{-1}$ (Recommended FYM). The third treatment was set by integrating NP and FYM as: Treatment $3\left(\right.$ T3) $=55 \mathrm{~kg} \mathrm{~N}^{-1}+23$ $\mathrm{kg} \mathrm{P}_{2} \mathrm{O}_{5} \mathrm{ha}^{-1}+6$ ton FYM ha ${ }^{-1}$ and treatment 4 (T4) was formulated from the rate some farmers of the area have been using as; T4= $27.5 \mathrm{~kg} \mathrm{~N} \mathrm{ha}^{-1}+11.5 \mathrm{~kg} \mathrm{P}_{2} \mathrm{O}_{5} \mathrm{ha}^{-1}+6$ ton FYM ha $\left.{ }^{-1}\right)$ and Treatment 5 (T5) $=$ No fertilizer applied (control).

\section{Experimental procedure}

The study was conducted in 2014 and 2015 cropping seasons. The work was executed on five farmers' field of $10 \mathrm{~m} \times 20 \mathrm{~m}$ plot size for each treatment. The treatments were arranged in Completely Randomized Block Design (CRBD) using farmers as replication. The trial was carried out with close involvement of all concerned stakeholders (participatory approach). Every selected farmer was made to prepare his own decomposed FYM on his backyard under similar procedure based on the orientation given before the onset of rainfall. The plots were made fine by repeated oxen plow. A recently released high yielding maize hybrid variety $(\mathrm{BH}-661)$ collected from Bako Agricultural Research Center (BARC) was used as a test crop and planted in rows with the spacing of 75 and $30 \mathrm{~cm}$ between rows and plants respectively. The well decomposed FYM and the inorganic Fertilizer (NP) was applied at planting. NP rate was computed from DAP (Diammonium Phosphate) (18-46-0) and Urea (46-0-0). Half of the calculated rates of urea applied at planting while the rest half was applied at 40 days after planting. Monitoring and data collection was made during the whole growing season. Agronomic (flowering date, plant height, maturity date, cob number, and grain yield) and soil data were collected during the trial period and subjected to SAS statistical software version 9.00 (SAS Institute Inc, 2002) for mean separation and profitability analysis.

\section{Soil and FYM sample collection and laboratory analysis}

Five soil samples were collected from the top $30 \mathrm{~cm}$ layer from experimental plots of each farmer before sowing and one composite sample was prepared per farmer plot. Similarly, a sample was taken from all decomposed FYM and composited to one sample per farmer with a total of five composite soil samples and five composite FYM samples and analyzed for their basic fertility characters (Table 1). After harvest a soil sample from the top $30 \mathrm{~cm}$ was collected from all farmers' plots for each treatment with a total of 25 soil samples. All the soil samples and FYM were sent to Water Works Design and Supervision Laboratory for analysis of basic soil fertility determining parameters (Table 6). The analysis was made using DTPA Extraction, $\mathrm{KH}_{2} \mathrm{PO}_{4}$ Extraction, Olsen extraction, Kjeldahl digestion, Walkley-Black method, Ammonium Acetate \& Instrumental methods.

\section{Grain sampling and analysis}

In order to minimize sampling error, the whole cobs in each plot were collected and shelled manually. A grain sample was collected from each treatment plot and sent to Ethiopia Water Works Design 
Table 1. Chemical analysis result of soil and FYM samples collected before sowing.

\begin{tabular}{|c|c|c|c|c|c|c|c|c|c|c|c|c|c|}
\hline \multirow{2}{*}{ Samp. } & \multirow{2}{*}{ PH } & \multirow{2}{*}{ EC } & \multicolumn{4}{|c|}{ Exch. cations (meq/100 gm of soil) } & \multirow{2}{*}{ CEC } & \multirow{2}{*}{ OC\% } & \multirow{2}{*}{$\mathrm{N}(\%)$} & \multirow{2}{*}{ Av. P } & \multirow[b]{2}{*}{ Av.K } & \multirow{2}{*}{ ESP } & \multirow{2}{*}{$\begin{array}{c}\text { Av.S } \\
\%\end{array}$} \\
\hline & & & $\mathrm{Na}$ & $\mathrm{K}$ & $\mathrm{Ca}$ & $\mathrm{Mg}$ & & & & & & & \\
\hline Soil & 5.32 & 0.075 & 1.18 & 0.62 & 17.1 & 5.7 & 40.08 & 2.21 & 0.19 & 0.04809 & 0.241 & 3.49 & 0.72 \\
\hline FYM & 7.01 & 0.97 & 1.07 & 0.76 & 38.90 & 13.00 & 69.71 & 9.22 & 0.99 & 105.64 & 0.30 & 1.74 & 5.40 \\
\hline
\end{tabular}

and Supervision Laboratory for analysis of basic grain nutrition indicators.

\section{Economic analysis}

All variable cost incurred including input and labor costs were recorded starting from compost and land preparation to the storage. Benefits obtained from the grain and Stover was estimated based on existing market price. The economic evaluation which includes a partial budget, dominance and marginal analysis were carried out as described by CIMMYT (1988) to compare the treatments advantages. All costs and benefits were calculated on hectare basis.

\section{RESULTS AND DISCUSSION}

\section{Yield and yield components}

Average yield of the two years showed that integrated application of farmyard manure and chemical NP fertilizers significantly $(P \leq 0.05)$ influenced plant height, number of ears plant ${ }^{-1}$ and grain yield of maize. Plant growth and yield were significantly lower for the control. Integrated application of 50\% recommended chemical NP fertilizers and 6 tons FYM ha ${ }^{-1}$ resulted in higher biological and grain yields during first year followed by the inorganic NP fertilizer application during second year growing period (Tables 2 and 3). Studies in Pakistan on maize fodder productivity and hybrid maize showed similar result (Lakho et al., 2004; Nasim et al., 2012). Study conducted on Rhodic Ferralsol soil in Togo ended up with high grain yield from integrated application of inorganic and FYM (Detchinli and Sogbedji, 2015) which is in line with the present findings. The application of FYM alone at recommended rate gave significantly lower grain yield compared to the integrated application. The reason for this lower grain yield may be due to the nutrient released from FYM alone could not nourish the high nutrient demand of maize (Wakene et al., 2005).

Wakene et al. (2005) explained the synergic effect of combined application of inorganic and organic fertilizer that the former nourish the plant best at the earlier stages while the later nourish at the later stages because of its slow nutrient release which was highly reflected in this study. Application of inorganic nitrogen and phosphorus source narrows $\mathrm{C}$ : $\mathrm{N}$ and $\mathrm{C}$ : $\mathrm{P}$ ratios which encourage the fast decomposition of organic manure and then mineralization of organic nitrogen and phosphorus (Mahmood et al., 2017). The integrated use of organic nutrient sources with inorganic fertilizer has the ability to increase the potential of organic fertilizer and improve the efficiency of inorganic fertilizer (Materechera and Salagae, 2002; Nasim et al., 2012). According to Nasim et al. (2012), finding the use of organic and inorganic fertilizers in proper combination (50:50) gave higher yields than the sole application of either of the fertilizer or manure particularly in hybrid maize in Pakistan.

Combined application of $50 \%$ recommended inorganic NP fertilizers and 6 tons FYM ha ${ }^{-1}$ resulted in 73 and $34 \%$, yield advantage when compared with the control and sole application of 12 tons FYM ha ${ }^{-1}$ respectively in year 1 (Table 2) and $38 \%$ and $22 \%$ in year 2 (Table 3 ) and 55 and $28 \%$ in average (Table 4 ) respectively. The result obtained was in line with Wakene et al. (2005) who reported higher grain yield of up to 74 qun/ha in western Ethiopia.

\section{Effect of treatments on grain nutritional composition}

The exchangeable basic cations ( $\mathrm{Na}, \mathrm{K}, \mathrm{Mg}$ and $\mathrm{Ca}$ ) and $\mathrm{P}$ composition of the grain showed statistical significant difference $(P<0.05)$ among the treatments. The highest composition of $\mathrm{Na}, \mathrm{K}, \mathrm{Ca}$ and $\mathrm{P}$ were found in $\mathrm{T} 1$ (Table 5 ; Figure 1). The organic carbon (OC \%) and $\mathrm{N}$ composition of grain showed statistical insignificance difference $(P>0.05)$ among the treatments. This may be due to the limited amount of $\mathrm{OC}$ and $\mathrm{N}$ in the soil. The highest $\mathrm{Mg}$ and $\mathrm{Ca}$ composition was observed in grain harvested from T2 (Sole FYM) due to the calcium and magnesium bicarbonate in the FYM. The high constituent of $\mathrm{K}$ and $\mathrm{P}$ was recorded from grain analysis result of the control treatment (T5). The result obtained indicated that the level of $P$ in grain decreased with the increasing level of FYM that indirectly implies the presence of calcium and magnesium in FYM due to limited translocation of $P$ to the plant tissue. Study made on similar soil type (Alfisol) in Delbo Atwaro watershed, southern Ethiopia indicated that $\mathrm{P}$ and $\mathrm{Cu}$ are not accessible by the plant because of the high fixation problem in the soil (Tena and Beyene, 2011). Although it was statistically insignificant (P. > 0.05); the highest $\mathrm{N}$ composition was observed in T3 (1/2 inorganic and 1/2 FYM). Similar to the P level, the mean organic carbon content of the grain was highest in T5 (control). As already mentioned above, high level of $\mathrm{Ca}$ was observed in T2 followed by $\mathrm{T} 1$. The result 
Table 2. Maize yield and yield component parameters obtained during 2014 growing season.

\begin{tabular}{lccccc}
\hline Treatments $^{*}$ & Flowering date & Plant height $(\mathbf{m})$ & Maturity date & Cob number/plot & Grain yield (qun/ha) \\
\hline T1 & 66 & $3.00^{\mathrm{ab}}$ & 127 & $839^{\mathrm{a}}$ & $77.50^{\mathrm{a}}$ \\
T2 & 71 & $2.92^{\mathrm{b}}$ & 131 & $719^{\mathrm{ab}}$ & $59.00^{\mathrm{bc}}$ \\
T3 & 70 & $3.20^{\mathrm{a}}$ & 128 & $922 \mathrm{a}$ & $79.75^{\mathrm{a}}$ \\
T4 & 70 & $2.93^{\mathrm{b}}$ & 128 & $763^{\mathrm{ab}}$ & $68.00^{\mathrm{ab}}$ \\
T5 & $2.57^{\mathrm{b}}$ & 137 & $577^{\mathrm{b}}$ & $45.75^{\mathrm{c}}$ \\
Mean & 76 & 2.92 & 130 & 764 & 66.00 \\
CV\% & 71 & 5 & 6 & 20 & 16 \\
P & 8 & 0.005 & Ns & 0.05 & 0.005 \\
\hline
\end{tabular}

${ }^{*} \mathrm{~T} 1=110 \mathrm{~kg} \mathrm{~N} \mathrm{ha}^{-1}+46 \mathrm{~kg} \mathrm{P}_{2} \mathrm{O}_{5} \mathrm{ha}^{-1}, \mathrm{~T} 2=12$ ton FYM ha ${ }^{-1}\left(\right.$ Recommended FYM $^{\text {l-1 }}, \mathrm{T} 3=55 \mathrm{~kg} \mathrm{~N}^{-1}+23 \mathrm{~kg} \mathrm{P}_{2} \mathrm{O}_{5} \mathrm{ha}^{-1}+6$ ton FYM ha , $\mathrm{T} 4=27.5 \mathrm{~kg} \mathrm{~N} \mathrm{ha}^{-1}+11.5 \mathrm{~kg} \mathrm{P}_{2} \mathrm{O}_{5} \mathrm{ha}^{-1}+6$ ton FYM ha ${ }^{-1}, \mathrm{~T} 5=$ Control.

Table 3. Maize yield and yield components recorded during 2015 growing season.

\begin{tabular}{lcccc}
\hline Treatments $^{*}$ & Plant height $(\mathbf{m})$ & Ear length $(\mathbf{c m})$ & Number of cobs per plot & Grain yield (qun/ha) \\
\hline T1 & $2.93^{\mathrm{a}}$ & $26.33^{\mathrm{a}}$ & $785^{\mathrm{a}}$ & $81.42^{\mathrm{a}}$ \\
T2 & $2.46^{\mathrm{a}}$ & $21.67^{\mathrm{c}}$ & $607^{\mathrm{bc}}$ & $65.08^{\mathrm{c}}$ \\
T3 & $2.90^{\mathrm{a}}$ & $25.00^{\mathrm{ab}}$ & $744^{\mathrm{a}}$ & $79.5^{\mathrm{ab}}$ \\
T4 & $2.82 \mathrm{a}$ & $23.5^{\mathrm{bc}}$ & $702^{\mathrm{ab}}$ & $72.92^{\mathrm{b}}$ \\
T5 & $1.91 \mathrm{c}$ & $17.83^{\mathrm{d}}$ & $549^{\mathrm{c}}$ & $57.50^{\mathrm{d}}$ \\
Mean & 2.61 & 22.87 & 677 & 71.28 \\
CV\% & 7 & 9.72 & 12 & 8 \\
P & 0.001 & 0.001 & 0.001 & 0.001 \\
\hline
\end{tabular}

*Abbreviations as in Table 2.

Table 4. Mean maize yield and yield components of 2014 and 2015 growing seasons.

\begin{tabular}{lccc}
\hline Treatments $^{*}$ & Mean plant height $(\mathbf{m})$ & Mean cobs number per plot & Mean grain yield (Qun/ha) \\
\hline T1 & $2.97^{\mathrm{ab}}$ & $812^{\mathrm{ab}}$ & $74.43^{\mathrm{a}}$ \\
T2 & $2.69^{\mathrm{c}}$ & $663^{\mathrm{c}}$ & $62.05^{\mathrm{c}}$ \\
T3 & $3.05^{\mathrm{a}}$ & $833^{\mathrm{a}}$ & $79.62^{\mathrm{a}}$ \\
T4 & $2.88^{\mathrm{b}}$ & $733^{\mathrm{bc}}$ & $70.37^{\mathrm{b}}$ \\
T5 & $2.24^{\mathrm{d}}$ & $564^{\mathrm{d}}$ & $51.48^{\mathrm{d}}$ \\
Mean & 2.76 & 721 & 68.59 \\
CV\% & 3 & 10 & 6 \\
P & 0.001 & 0.001 & 0.0001 \\
\hline
\end{tabular}

${ }^{*}$ Abbreviations as in Table 2.

Table 5. Effect of treatments on nutrient composition of maize grain.

\begin{tabular}{|c|c|c|c|c|c|c|c|}
\hline \multirow{2}{*}{ Trt. } & \multicolumn{4}{|c|}{ Exchangeable basic cations (PPM) } & \multirow{2}{*}{$\mathrm{OC}(\%)$} & \multirow{2}{*}{ Total N (\%) } & \multirow{2}{*}{$\mathrm{P}\left(\mathrm{mg} \mathrm{P} \mathrm{P}_{2} \mathrm{O}_{5} \mathrm{~kg}\right.$ grain) } \\
\hline & $\mathrm{Na}^{+}$ & $\mathrm{K}^{+}$ & $\mathrm{Mg}^{++}$ & $\mathrm{Ca}^{++}$ & & & \\
\hline T1 & $1948.8^{\mathrm{a}}$ & $1535.9^{\mathrm{a}}$ & $2591.9^{b}$ & $16595^{\mathrm{a}}$ & 54.415 & 0.832 & $9462^{a}$ \\
\hline T2 & $1052.7^{c}$ & $1183.9^{b}$ & $3127.7^{\mathrm{a}}$ & $17804^{\mathrm{a}}$ & 52.177 & 0.816 & $5276^{b}$ \\
\hline T3 & $1387.8^{\mathrm{bc}}$ & $1617.7^{\mathrm{a}}$ & $2270.5^{\mathrm{bc}}$ & $12886^{\mathrm{b}}$ & 51.841 & 0.935 & $5668^{b}$ \\
\hline T4 & $1167.1^{\mathrm{c}}$ & $1569^{\mathrm{a}}$ & $2166.3^{c}$ & $13134^{\mathrm{b}}$ & 53.572 & 0.768 & $5807^{b}$ \\
\hline T5 & $1656.4^{\mathrm{ab}}$ & $1620.2^{\mathrm{a}}$ & $2120.5^{c}$ & $12253^{b}$ & 65.307 & 0.800 & $10524^{\mathrm{a}}$ \\
\hline Mean & 1468.24 & 1522.2 & 2419.99 & 14362 & 55.640 & 0.830 & 7345 \\
\hline CV & 19 & 9 & 11 & 13 & 15 & 16 & 22 \\
\hline$P$ & 0.005 & 0.05 & 0.005 & 0.005 & NS & NS & 0.005 \\
\hline
\end{tabular}



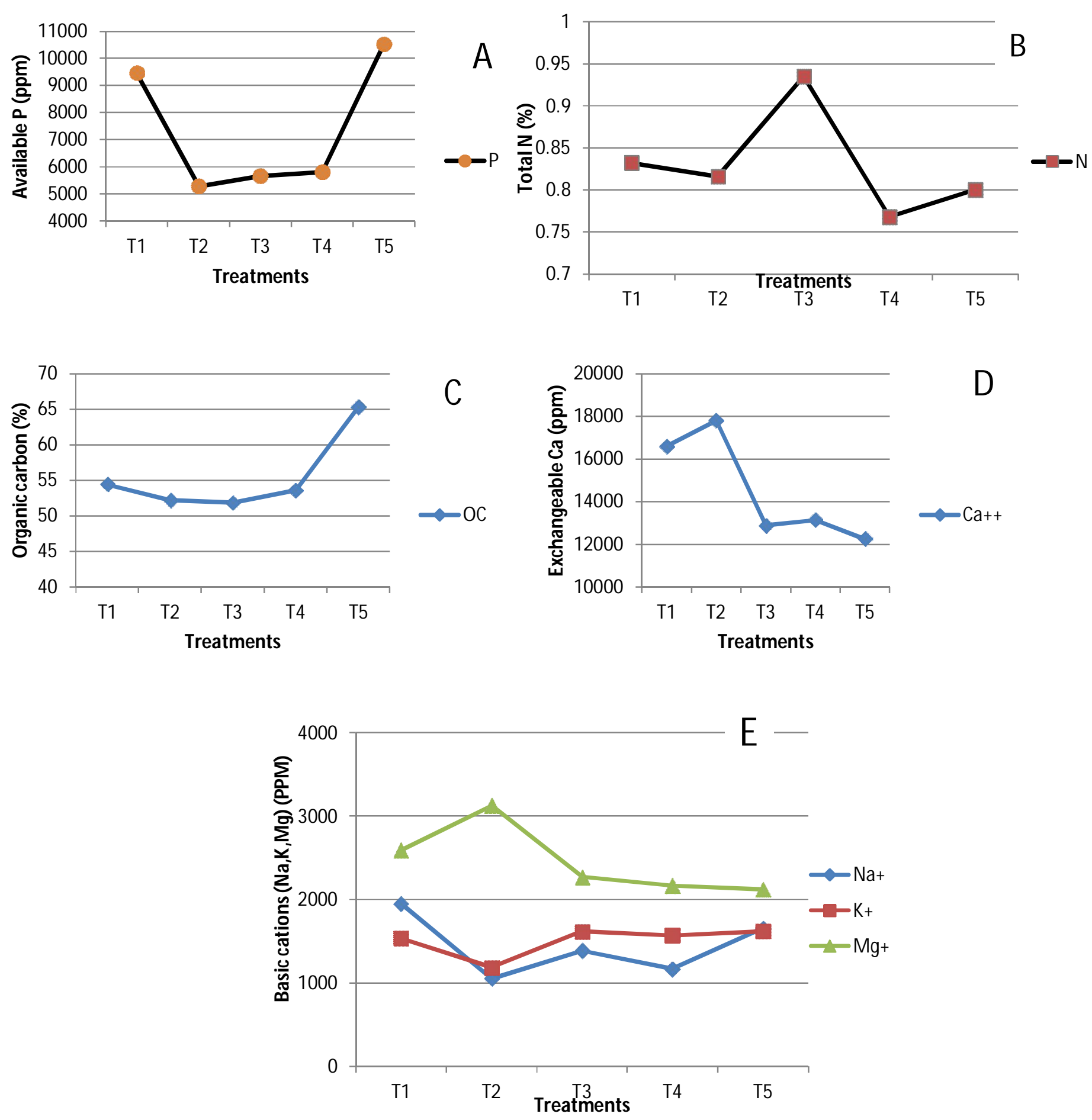

Figure 1. Effect of treatments on nutrient composition of maize grain.

obtained indicated that $\mathrm{Ca}$ and $\mathrm{Mg}$ composition in grain has inverse relationship with $\mathrm{Na}$ and $\mathrm{K}$. As a result of that $\mathrm{Ca}$ and $\mathrm{Mg}$ have strong energy of adsorption ( $\mathrm{Ca}>\mathrm{Mg}>$ $\mathrm{K}>\mathrm{Na}$ ) that makes them more abundant as an exchangeable cation than $\mathrm{K}$ and $\mathrm{Na}$ (Tena and Beyene, 2011).

\section{Effect of the treatments on soil fertility parameters}

Soil fertility parameters considered showed insignificant statistical difference $(P>0.05)$ among the treatments. The $\mathrm{pH}$ value of the soil indicated that the study soils are categorized in the range of strong acidic soil while 


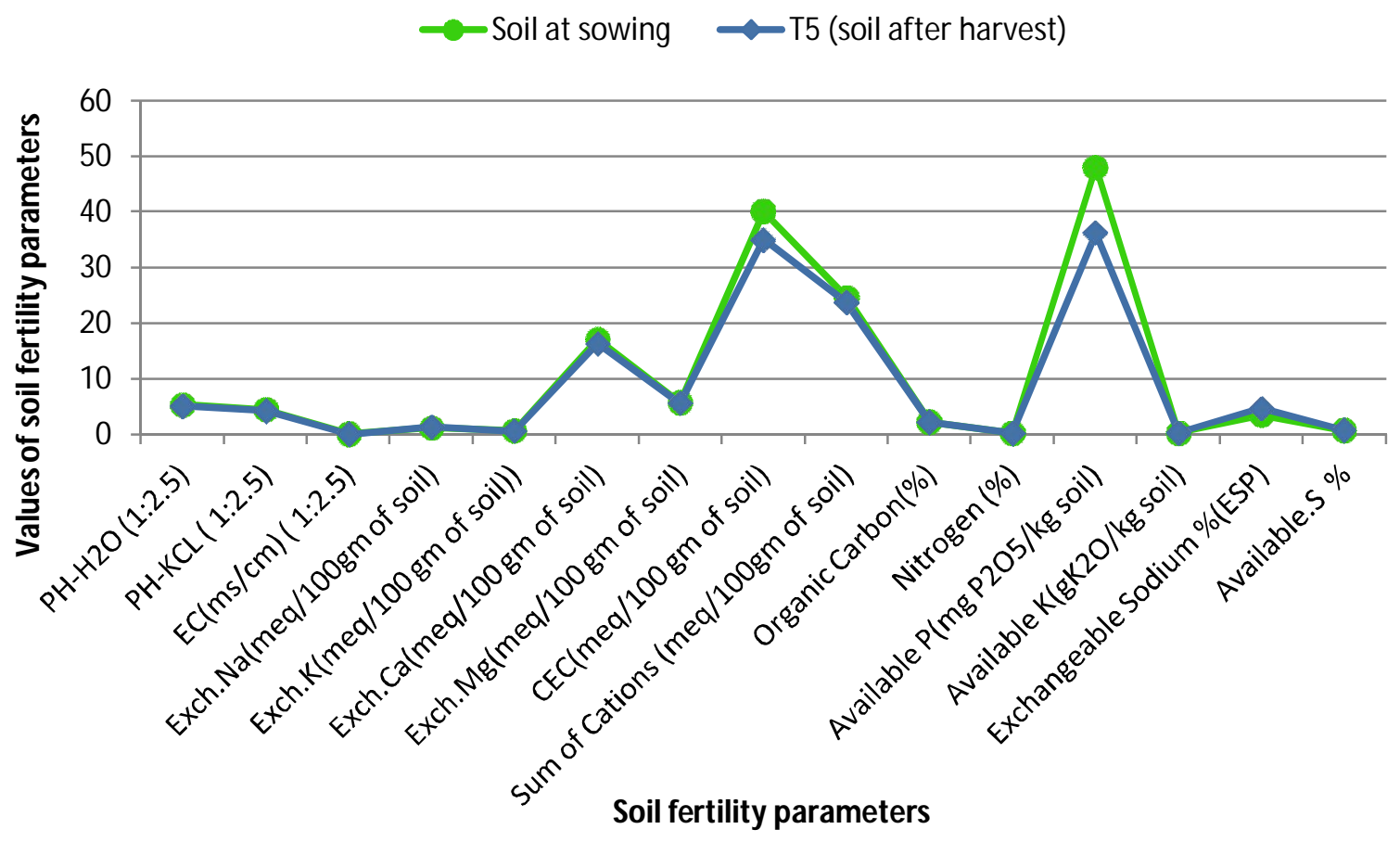

Figure 2. Chemical character of the soil before sowing and after harvest.

optimum maize yield is expected around soil $\mathrm{pH} 6.8$ (Doran and Jones, 1996). An increment was observed in exchangeable $\mathrm{Na}$ and exchangeable sodium percentage (ESP) in the soil after harvest, while in the contrary, exchangeable $\mathrm{Ca}, \mathrm{CEC}$, and available $\mathrm{P}$ were declined (Figure 2) that indicates the deterioration of the soil. The mean difference values indicated that application of inorganic fertilizer alone increased soil $\mathrm{PH}$, exchangeable $\mathrm{Na}$, and available $\mathrm{S}$. The nil consequence of both fertilizer type on organic carbon and total $\mathrm{N}$ recognized in this study was in line with Okwuagwu et al. (2003) findings. The rise of $\mathrm{pH}$ in this treatment could be due to the increments of Exchangeable sodium and exchangeable sodium percentage observed in the treatment effect. Sole application of farmyard manure resulted in an increase in soil exchangeable $\mathrm{K}, \mathrm{Mg}$, and available $\mathrm{K}$ and $\mathrm{S}$ when compared to the control. Application of 50:50 inorganic and FYM (T3) resulted in an increment of soil exchangeable sodium, exchangeable sodium percentage and available S. A decline in level of exchangeable $\mathrm{K}$ and exchangeable $\mathrm{K} \%$ was noticed in plots treated with FYM (Table 6). Lemanowicz et al. (2014) investigated as FYM application enhances availability of sulphur for plants. This could be the possible reason for the decline of $S$ in soils of sole FYM and combined application when compared to the sole inorganic fertilizer application.

\section{Economic analysis}

Among the five treatments, the costs of urea, DAP, manure, labor cost for weeding, harvesting and desheathing, fertilizer and manure application and threshing were the costs that vary from treatment to treatment. All the other costs like cost of seed, labor for row making and planting were similar. The total amount of threshing cost for a single treatment is the product of adjusted grain yield in $\mathrm{kg}$ per treatment multiplied by 0.12 ETB. As clearly seen in the partial budget analysis result, the net benefit obtained from treatment three (T-3, 50\% NP recommendation and 50\% FYM recommendation) was greater than the net benefits from other three treatments and the control plot (Table 7).

After finding the results of the partial budget analysis, the second step is doing the dominance analysis. In order to do the dominance analysis, first rearranging the treatments is needed in ascending order of the total costs that vary, the treatment with the least cost that vary will come on the first row followed by the second lowest cost treatment and at the end the treatment with the highest cost that vary (Table 8).

Although the gross benefit obtained from the first four treatments was greater than the gross benefit earned from the control; the result of the dominance analysis showed that T2 (no NP and 12 ton of FYM) was dominant. That means the net benefits of 19,494.71 ETB (with 8,010.6 total costs that vary) was found lower than the net benefits earned from T-1, 26,050.19 ETB (with 7,559.5 ETB total costs that vary) (Table 8). The cost stated in this economic analysis is on the bases of Ethiopian birr in which $1 \mathrm{USD}=22 \mathrm{ETB}$ as of the time this activity was handled.

Following this, marginal analysis was made. Acording 
Table 6. Chemical property of the soil of the study site after harvest.

\begin{tabular}{|c|c|c|c|c|c|c|c|c|c|c|c|c|c|c|c|}
\hline $\begin{array}{l}\text { Treatm } \\
\text { ents }\end{array}$ & $\begin{array}{c}\mathrm{PH}-\mathrm{H}_{2} \mathrm{O} \\
(1: 2.5)\end{array}$ & $\begin{array}{c}\text { PH-KCL } \\
(1: 2.5)\end{array}$ & $\begin{array}{c}\text { EC } \\
(\mathrm{ms} / \mathrm{cm}) \\
(1: 2.5)\end{array}$ & $\begin{array}{l}\text { Exch.Na } \\
\text { (meq/100 g } \\
\text { of soil) }\end{array}$ & $\begin{array}{c}\text { Exch.K } \\
\text { (meq/100 } \\
\text { g of } \\
\text { soil)) }\end{array}$ & $\begin{array}{l}\text { Exch.Ca } \\
\text { (meq/100 } \\
\mathrm{g} \text { of soil) }\end{array}$ & $\begin{array}{l}\text { Exch.Mg } \\
\text { (meq/100 } \\
\text { g of soil) }\end{array}$ & $\begin{array}{c}\text { CEC } \\
\text { (meq/100 } \\
\mathrm{g} \text { of soil) }\end{array}$ & $\begin{array}{l}\text { Sum of } \\
\text { cations } \\
\text { (meq/100 } \\
\mathrm{g} \text { of soil) }\end{array}$ & $\begin{array}{c}\text { Organic } \\
\text { carbon } \\
(\%)\end{array}$ & $\begin{array}{c}\text { Nitrogen } \\
(\%)\end{array}$ & $\begin{array}{l}\text { Availabl } \\
\text { e P (g } \\
\mathrm{P}_{2} \mathrm{O}_{5 / k g} \\
\text { soil) }\end{array}$ & $\begin{array}{c}\text { Available } \\
\mathrm{K} \\
\text { (gK } \\
\text { solil) }\end{array}$ & $\begin{array}{l}\text { Exchange } \\
\text { able } \\
\text { Sodium \% } \\
\text { (ESP) }\end{array}$ & $\begin{array}{c}\text { Available.S } \\
\%\end{array}$ \\
\hline $\mathrm{T} 1$ & $5.45^{a}$ & $4.62^{\mathrm{a}}$ & 0.04 & 1.27 & $0.55^{\mathrm{ab}}$ & 16.05 & 5.56 & 38.54 & 23.44 & 1.49 & 0.18 & 0.07 & $0.21^{b}$ & 3.88 & 1.07 \\
\hline T2 & $5.18^{a b}$ & $4.42^{\mathrm{ab}}$ & 0.027 & 1.31 & $0.63^{a}$ & 16.02 & 5.77 & 35.66 & 23.72 & 2.1 & 0.2 & 0.03512 & $0.245^{a}$ & 4.04 & 1.01 \\
\hline T3 & $5.11^{b}$ & $4.31^{\mathrm{ab}}$ & 0.025 & 1.31 & $0.56^{a b}$ & 16.06 & 5.57 & 37.74 & 23.5 & 2 & 0.19 & 0.04116 & $0.221^{\mathrm{ab}}$ & 3.93 & 0.75 \\
\hline T4 & $4.95^{b}$ & $4.1^{\mathrm{b}}$ & 0.03 & 1.31 & $0.52^{b}$ & 16.42 & 5.77 & 36.1 & 24.03 & 2.08 & 0.18 & 0.04022 & $0.205^{b}$ & 4.31 & 0.86 \\
\hline T5 & $5.1^{b}$ & $4.25^{b}$ & 0.035 & 1.35 & $0.54^{b}$ & 16.28 & 5.56 & 35.02 & 23.73 & 2.25 & 0.21 & 0.03622 & $0.208^{b}$ & 4.67 & 0.70 \\
\hline Mean & 5.16 & 4.35 & 0.032 & 1.31 & 0.56 & 16.17 & 5.64 & 36.61 & 23.68 & 1.98 & 0.19 & 0.044 & 0.218 & 4.16 & 0.87 \\
\hline CV & 12 & 5 & - & 17 & 9 & 5 & 8 & 6 & 5 & 23 & 16 & 23 & 8 & 13 & - \\
\hline$P$ & 0.03 & 0.043 & NS & NS & 0.08 & NS & NS & NS & NS & NS & NS & 0.005 & 0.046 & NS & NS \\
\hline
\end{tabular}

Table 7. Partial budget analysis for an integrated farmyard manure and NP fertilizers application on maize at Bako Tibe district.

\begin{tabular}{|c|c|c|c|c|c|}
\hline \multirow{2}{*}{ Parameters } & \multicolumn{5}{|c|}{ Treatment } \\
\hline & $\mathrm{T}-1$ & T-2 & T-3 & T-4 & T-5 \\
\hline Average grain yield (kg/ha) & 7,443 & 6,205 & 7,962 & 7,037 & 5148 \\
\hline Adjusted grain yield (kg/ha) & $7,070.9$ & $5,894.8$ & $7,563.9$ & $6,685.2$ & $4,890.6$ \\
\hline Gross field benefits, grain (ETB/ha) & 26515.69 & 22105.31 & 28364.63 & 25069.31 & 18339.75 \\
\hline Gross field benefits, straw (ETB/ha) & 7,094 & 5,400 & 7,300 & 6,225 & 4,190 \\
\hline Total gross field benefits (ETB/ha) & $33,609.69$ & $27,505.31$ & $35,664.63$ & $31,294.31$ & $22,529.75$ \\
\hline Cost of urea (ETB/ha) & 2,120 & 0 & 1,060 & 530 & 0 \\
\hline Cost of DAP (ETB/ha) & 1,380 & 0 & 690 & 345 & 0 \\
\hline Cost of manure (ETB/ha) & 0 & 4,200 & 2,100 & 2,100 & 0 \\
\hline Fertilizer and manure application labor cost (ETB/ha) & 640 & 800 & 900 & 884 & 0 \\
\hline weeding labor cost (ETB/ha) & 880 & 928 & 710 & 840 & 1,072 \\
\hline Cost of harvesting and de-leafing (ETB/ha) & 1,656 & 1,410 & 1,776 & 1,464 & 940 \\
\hline Cost of threshing (ETB/ha) & 883.5 & 672.6 & 909.2 & 775.2 & 521.6 \\
\hline Total costs that vary $(\mathrm{ETB} / \mathrm{ha})$ & $7,559.5$ & $8,010.6$ & $8,145.2$ & $6,938.2$ & $2,533.5$ \\
\hline Net benefits (ETB/ha) & $26,050.19$ & $19,494.71$ & $27,519.43$ & $24,356.11$ & $19,996.25$ \\
\hline
\end{tabular}

to the marginal result analysis, treatments were placed as $T_{3}, T_{1}$ and $T_{4}$ based on the benefits farmers can earn $27,519.43,26,050.19$ and $24,356.11 \mathrm{ETB} / \mathrm{ha}$ respectiveley which was much bigger than the net benefits earned from control $(19,996.25 \mathrm{ETB} / \mathrm{ha})$. This study finding is in line with the result reported from Tselemit District of Northern Ethiopia (Gebrtsadkan and Assefa,
2015). Result obtained in Pakistan showed that use of FYM alone resulted in lower productivity of physical maize fodder and revenue income when compared to integrated application of both FYM 
Table 8. Dominance analysis for integrated farmyard manure and NP fertilizers application on hybrid maize at Bako Tibe.

\begin{tabular}{lcc}
\hline Treatment & Costs that vary (ETB/ha) & Net benefit (ETB/ha) \\
\hline T-5 & $2,533.5$ & $19,996.25$ \\
T-4 & $6,938.2$ & $24,356.11$ \\
T-1 & $7,559.5$ & $26,050.19$ \\
T-2 & $8,010.6$ & $19,494.71 \mathrm{D}$ \\
T-3 & $8,145.2$ & $27,519.43$ \\
\hline
\end{tabular}

Table 9. Marginal analysis for integrated farmyard manure and NP fertilizers application on maize at Bako Tibe.

\begin{tabular}{lccccc}
\hline Treatment & $\begin{array}{c}\text { Costs that vary } \\
\text { (ETB/ha) }\end{array}$ & $\begin{array}{c}\text { Marginal costs } \\
\text { (ETB/ha) }\end{array}$ & $\begin{array}{c}\text { Net benefit } \\
\text { (ETB/ha) }\end{array}$ & $\begin{array}{c}\text { Marginal benefits } \\
\text { (ETB/ha) }\end{array}$ & $\begin{array}{c}\text { Marginal rate of } \\
\text { return (\%) }\end{array}$ \\
\hline T-5 & $2,533.5$ & & $19,996.25$ & & \\
T-4 & $6,938.2$ & $4,404.70$ & $24,356.11$ & $4,359.86$ & 99.0 \\
T-1 & $7,559.5$ & $5,026.00$ & $26,050.19$ & $6,053.94$ & 120 \\
T-3 & $8,145.2$ & $5,611.43$ & $27,519.43$ & $7,523.18$ & 134 \\
T3 & $8,145.2$ & 585.70 & $27,519.43$ & $1,469.24$ & 251 \\
\hline
\end{tabular}

and inorganic fertilizers (Lakho et al., 2004). The marginal rate of return indicated that the farmer can earn an additional net income of 0.99 ETB for every 1 ETB invested to shift from $T_{5}$ to $T_{4}$ after returning the additional investment required to shift from $T_{5}$ to $T_{4}$ which is 4,404.65 ETB, and the farmer can earn an additional net income of 1.20 ETB for every ETB invested to shift from $T_{5}$ to $T_{1}$ after returning the additional investment required to shift from $T_{5}$ to $T_{1}$ which was 5,026.00 ETB. Finally the farmer can earn an additional net income of 1.34 ETB for every 1 ETB invested to shift from $T_{5}$ to $T_{3}$ after returning the additional investment required to shift from $T_{5}$ to $T_{3}$ which was 5,611.43 ETB (Table 9). If the farmer planned to shift from T1 (from the recommended NP fertilizer application to the $50 \%$ of the recommended NP with $50 \%$ of the recommended FYM application) to T3 the farmer can earn an additional of 2.51 ETB for every 1 ETB invested. Study made in Chiro Western Ethiopia also gave similar interpretation on the economic benefit of integrated use of NP and FYM than the sole application of each component (Zelalem Bekeko, 2014). Similar study carried out in Togo depicted that application of $1 / 2$ rate of recommended NP (200kg NPK (15:15:15) + $46 \mathrm{~kg}$ Urea/ha) and $1 / 2$ rate of recommend FYM (6t/ha) resulted in $56 \%$ and $20 \%$ more benefit than the recommended FYM and inorganic fertilizer rate respectively (Detchinli and Sogbedji, 2015)

\section{CONCLUSION AND RECOMMENDATIONS}

The current scenarios of maize production in Western part of Ethiopia call for appropriate additions of nutrient to the soil to obtain optimum maize productivity and profitability. The best option for soil fertility management in this regard is the integrated soil fertility management that implies a combined use of organic and inorganic nutrient sources. The combination of $6 \mathrm{t} / \mathrm{ha} F Y M+55 \mathrm{~kg}$ $\mathrm{N} / \mathrm{ha}+23 \mathrm{~kg} \mathrm{P} / \mathrm{ha}$ appeared to be a very promising result among the treatments compared in the present study for maize productivity and economic perspectives. Fertilization with FYM alone resulted in less profit as compared to the control, indicating that the strategy of organic amendment alone may be encouraged when seen insight of environmental prospects but was not economically profitable. Different organic and inorganic fertilizers combination rates were recommended for different areas by different innovators in Ethiopia which their rates are approaching almost half of each component but not exactly. Further investigation should be made to recommend appropriate rates of each component based on productivity and profitability of the sector. This study result is encouraging for farmers to use integrated application of FYM and inorganic fertilizer with a combination of half of the recommended rate of each component.

\section{ACKNOWLEDGEMENTS}

The authors gratefully acknowledge CASCAPE project for funding this study. The contribution of Bako Tibe district office of agriculture, experts and development agents in data collection and timely field supervision is highly acknowledged. The host farmers are highly appreciated for their collaboration and active 


\section{participation in executing the experiment.}

\section{REFERENCES}

Abate T, Shiferaw B, Menkir A, Wegary D, Kebede $\mathrm{Y}$, Tesfaye $\mathrm{K}$, Kassie M, Bogale G, Tadesse B, Keno T, 2015. Factors that transformed maize productivity in Ethiopia. Food Security, 7(5): 965981.

Bekeko Z, 2014. Evaluation of enriched farmyard manure and inorganic fertilizers profitability in hybrid maize $(\mathrm{BH}-140)$ producion at west Hararghe zone, eastern Ethiopia. J Genet Environ Resour Conserv, 2(1): 83-89.

Dadhi L, Gedeno G, Kumsa T, Degu G, 1987. Bako mixed farming zone. Diagnostic Survey Report No. 1. Institute of Agricultural Research, Department of Agricultural Economics and Farming Systems Research, Addis Ababa, Ethiopia.

Demeke M, 2012. Analysis of incentives and disincentives for maize in Ethiopia. Technical notes series, MAFAP, FAO, Rome.

Detchinli KS, Sogbedji JM, 2015. Yield performance and economic return of maize as affected by nutrient management strategies on ferralsols in costal western Africa. Eur Sci J, 11(27): 312-324

Doran JW, Jones AJ, 1996. Method for assessing soil quality. SSSA spec. publ. 49, SSSA, Madison, Wi, doi: 102136/SSSAspecpub49.

Gebrtsadkan G, Assefa D, 2015. Evaluating the effect of integrated use of farm yard manure and urea on the socio economic performance of tomato (Lycopersicon esculentum Mill) at Tselemti Woreda, North western Tigray, Ethiopia. J Biol Agric Healthcare, 5(9): 158-164.

Getachew G, 2015. Fertility mapping of soils of Bako Tibe district, west Shewa zone of Oromia regional state, Ethiopia. A thesis submitted to Haramaya University, Haramaya.

Lakho AA, Oad FC, Solangi AA, Siddiqui MH, 2004. Economics of maize fodder under organic and inorganic fertilizers. Int J Agric Biol, 6(6): 1172-1173.

Lemanowicz J, Siwik-Ziomek A, Koper J, 2014. Effects of farmyard manure and nitrogen fertilizers on mobility of phosphorus and sulphur in wheat and activity of selected hydrolases in soil. Int Agrophys, 28: 49-55.

Mahmood F, Khan I, Ashraf U, Shahzad T, Hussain S, Shahid M, Abid M, Ullah S, 2017. Effects of organic and inorganic manures on maize and their residual impact on soil physico-chemical properties. J Soil Sci Plant Nutr, 17(1): 22-32.

Materechera SA, Salagae AM, 2002. Use of partially decomposed cattle and chicken manures amended with wood-ask in two South African arable soils with contrasting texture effect on nutrient uptake, early growth and dry matter yield of maize. Commun Soil Sci Plant Anal, 33(1\&2): 179-200.

McCann JC, 2005. Maize and grace: Africa's encounter with a new world crop, 1500-2000. Cambridge: Harvard University Press.

Mesfin A, 1998. Nature and management of Ethiopian soils. Alemaya University of Agriculture, Ethiopia.
Nasim W, Ahmad A, Khaliq T, Waijd A, Munis MFH, Chaudhry HJ, Maqbool MM, Ahmad S, Hammad HM, 2012. Effect of organic and inorganic fertilizer on maize hybrids under agro-environmental conditions of Faisalabad-Pakistan. Afr J Agric Res, 7(17): 2713-2719.

Negassa W, Gebrekidan H, Friesen DK, 2005. Integrated use of farmyard manure and NP fertilizers for maize on farmers' fields. J Agric R Devt Trop Subtrop, 106(2): 131-141.

Okwuagwu MI, Alleh ME, Osemwota IO, 2003. The effects of organic and inorganic manure on soil properties and yield of okra in Nigeria. Afr Crop Sci Conf Proc, 6: 390-393.

Tena W, Beyene S, 2011. Identification of growth limiting nutrient(s) in Alfisols: Soil physic-chemical properties, nutrient concentrations and biomass yield of maize. Am J P Nut Fert Tech, 1(1): 23-35.
Citation: Gemechu B, Etana A, Senbeta F, Tolossa D, 2017. Effect of integrated farmyard manure and NP fertilizers use on hybrid maize yield and soil properties in western Ethiopia. Net J Agric Sci, 5(3): $85-$ 93. 